\title{
ANALYSIS OF THE CONTENT OF MACRO- AND MICROELEMENTS IN THE LEAVES OF SEA BUCKTHORN (Hippophaë rhamnoides L.)
}

\section{ANALIZA ZAWARTOŚCI MAKRO- I MIKROSKŁADNIKÓW W LIŚCIACH ROKITNIKA ZWYCZAJNEGO (Hippophaë rhamnoides L.)}

\author{
Department of Agronomy, West Pomeranian University of Technology, Szczecin, Poland \\ ${ }^{1}$ Department of Pig Breeding, Animal Nutrition and Food, West Pomeranian University \\ of Technology, Szczecin, Poland \\ 2Department of Chemistry, Microbiology and Environmental Biotechnology, West Pomeranian \\ University of Technology, Szczecin, Poland
}

\begin{abstract}
Streszczenie. Rokitnik zwyczajny wykorzystywany jest na całym świecie przede wszystkim ze względu na wysoką wartość odżywczą i unikatowe właściwości lecznicze. Jest rośliną o małych wymaganiach klimatyczno-glebowych. Przeprowadzone badania miały na celu określenie zmian składu mineralnego liści rokitnika zwyczajnego (Hippophae rhamnoides L. ssp. Rhamnoides) w zależności od podłoża i upływu czasu oraz oceny możliwości wzrostu na glebach zasolonych i zdegradowanych. Oznaczono następujące pierwiastki chemiczne: azot, fosfor, potas, wapń, magnez, żelazo, mangan, cynk, sód, molibden, chrom, ołów i kadm. Krzewy rokitnika zwyczajnego (Hippophae rhamnoides L. ssp. Rhamnoides), z których w czerwcu 2015 roku pobrane zostały liście, zlokalizowane były w czterech miejscach na terenie Szczecina. Gleby, na których rosły krzewy rokitnika, to gleby zasadowe. Różna lokalizacja miejsc rosnących krzewów rokitnika zwyczajnego (Hippophae rhamnoides L.) i zastosowane nawożenie spowodowały zróżnicowanie ilości fosforu, potasu, wapnia i magnezu w liściach tej rośliny, natomiast nie odnotowano wpływu na zmiany w nich zawartości azotu. Próbki liści pobrane rok wcześniej zawierały więcej azotu i fosforu, a mniej wapnia i magnezu. Liście rokitnika zwyczajnego, rosnącego nad brzegiem rzeki Odry, zawierały ponaddziesięciokrotnie więcej sodu, dwukrotnie więcej żelaza, trzykrotnie więcej manganu, w porównaniu z zawartością w liściach krzewów rosnących w innych miejscach. Nie stwierdzono zróżnicowania ilości manganu w liściach w zależności od lat badań, natomiast liście pobrane rok wcześniej zawierały więcej żelaza. W liściach rokitnika (Hippophae rhamnoides L.) nie stwierdzono molibdenu i chromu, ołowiu i kadmu. Pobieranie przez rokitnik dużych ilości sodu, wapnia i magnezu wskazuje na możliwość jego uprawy na glebach zasolonych i zdegradowanych.
\end{abstract}

Key words: Hippophaë rhamnoides L., nitrogen, phosphorus, potassium, calcium, magnesium, iron, manganese, zinc, sodium.

Słowa kluczowe: Hippophaë rhamnoides L., azot, fosfor, potas, wapń, magnez, żelazo, mangan, cynk, sód.

\section{INTRODUCTION}

Sea buckthorn (Hippophaë rhamnoides L.) is a medium-sized deciduous tree or large bush with thorny branches. Two subspecies of sea buckthorn can be distinguished.

Corresponding author - Adres do korespondencji: Marzena Gibczyńska, Department of Chemistry, Microbiology and Environmental Biotechnology, West Pomeranian University of Technology, Szczecin, Juliusza Słowackiego 17, 71-434 Szczecin, Poland, e-mail: marzena.gibczynska@zut.edu.pl 
Subspecies Hippophae rhamnoides subsp. rhamnoides is a strongly thorny shrub with short, rigidly erected branches and dense inflorescences. Its fruits have a unique composition with high levels of nutrients with high potency as a dietary and medicinal supplement (Sajfrtova and Sovova 2012). They contain large amounts of vitamin $C$ and $E$, some $B$ vitamins and provitamin A, acids: palmitic, myristic, stearic, oleic, linoleic and linolenic, carotene, a variety of flavonoids and alkaloids, as well as free amino acids (Kallio et al. 2002; Yang and Kallio 2002; Dulf 2012; Giuffrida 2012; Magnuszewska and Krogulec 2013; Tulsawani et al. 2013; Pop et al. 2014).

Particular interest is associated with the chemical composition of sea buckthorn. However, in addition to the fruits, bark and leaves of sea buckthorn are good sources of large amounts of bioactive substances. They contain many antitumor and antioxidant compounds with immuno-modulatory and anti-inflammatory effects, as well as flavonoids and phenolic acids (Beveridge et al. 1999; Saggu et al. 2007; Saini et al. 2010; Kumar et al. 2011; Zheng et al. 2012). For comparison, sea buckthorn contains carotenes, carotenoid esters and chlorophyll in the number of 27 and in leaves there are 11 of them (Pop et al. 2014). In ancient Greece, sea buckthorn leaves was known as good feed for horses (Niesteruk et al. 2013). Study results reported by Heinäaho et al. (2006) suggest that methods for sea buckthorn (Hippophae rhamnoides L. ssp. rhamnoides) cultivation affected the quantities of valuable chemicals in leaves: gallic acid, pentagalloylglucose, quercetin, monocoumaroyl astragalin, or tanins. Presence of bioactive substances in plants is related to the amount of macronutrients and microelements.

The study was conducted to determine changes mineral compounds in leaves of sea buckthorn (Hippophae rhamnoides L. ssp. rhamnoides), depending on the substrate type and the passage of time and assessment of the potential for sea buckthorn growth on saline and degraded soil.

\section{MATERIAL AND METHODS}

Shrubs of sea buckthorn (Hippophae rhamnoides L. ssp. rhamnoides), of which leaves were collected in June 2015, growing in the Dolna Odra Power Station at Nowe Czarnowo,

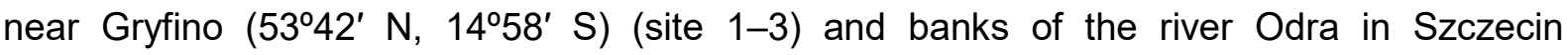
$\left(53^{\circ} 26^{\prime} 17^{\prime \prime} \mathrm{N}, 14^{\circ} 32^{\prime} 32^{\prime \prime} \mathrm{E}\right)$ (site 4), Poland. Samples of leaves (about half kilogram from one site) were taken from the same shrubs as in the previous year (Jaroszewska et al. 2016). Leaves to the analysis were collected from the outside of the bush, with half of their height. The leaves taken from the one year old shoots without any signs of ageing or mechanical damage.

The soils, on which sea buckthorn bushes grow are alkaline and contained organic mass in the range $10.5-28.4 \mathrm{~g} \cdot \mathrm{kg}^{-1} \mathrm{DM}$. The soil characteristics of individual sites are as follows:

- site 1 - native sandy soil;

- site 2 - sandy soil recultivated using coal ash with NPK, 60-70-70 + sewage sludge at $1: 1$ ratio;

- site 3 - Sandy soil recultivated with coal ash + bark from conifers + sewage sludge compost at $1: 2: 4$ ratio;

- site 4 - sandy soil on the banks of the Odra river near the road. 
After mineralization of leaf samples in sulfuric acid $(\mathrm{VI})$ solution in combination with $\mathrm{H}_{2} \mathrm{O}_{2}$, the nitrogen content was determined by means of Kjeldahl method (PN-EN ISO 20483: :2014-02), while phosphorus using spectrometric method (PN-ISO 6491:2000P).

Total metals contents ( $\mathrm{K}, \mathrm{Ca}, \mathrm{Mg}, \mathrm{Fe}, \mathrm{Mn}, \mathrm{Zn}, \mathrm{Na}, \mathrm{Mo}, \mathrm{Cr}, \mathrm{Pb}$ and $\mathrm{Cd}$ ) were determined in leaf samples after wet combustion in mixture of nitric $\operatorname{acid}(\mathrm{V})$ with chloric $\operatorname{acid}(\mathrm{VII})$ at $1: 1$ ratio (PN-EN ISO 6869:2002P). Analyses were carried out applying Atomic Absorption Spectrometer Apparatus (Thermo Fisher Scientific iCE 3000 Series).

The statistical analysis of the results was conducted using Statistica 10 software. In order to determine the significance of the differences in chemical composition of the analysed leaves one way analysis of variance (ANOVA) in complete randomised design was conducted in 3 replication. For the purpose of determining significant differences between mean values, the Tukey test was conducted at $P<0.05$.

\section{RESULTS AND DISCUSSION}

\section{Macronutrients (N, P, K, Ca, Mg)}

Chemical composition of leaves reflects the nutritional status of shrubs and fruits into basic macronutrients, directly related to biochemical processes occurring at plants. The amount of nitrogen in the sea buckthorn leaves did not vary despite different locations of shrubs and it was $31.62 \mathrm{~g} \mathrm{~N} \cdot \mathrm{kg}^{-1} \mathrm{DM}$. It was within the same range as the optimum nitrogen content in black currant leaves determined by the National Plant Protection and Seed Inspection (27-32 g N $\left.\cdot \mathrm{kg}^{-1}\right)\left(27-32 \mathrm{~g} \mathrm{~N} \cdot \mathrm{kg}^{-1}\right)$ - Łabanowska (2016).

Nitrogen, phosphorus, potassium. The amount of phosphorus in leaves of sea buckthorn (Hippophae rhamnoides L.) varied from 2.33 to $2.79 \mathrm{mg} \mathrm{P} \cdot \mathrm{kg}^{-1} \mathrm{DM}$. For comparison, this was the optimal range for black currant leaves (Łabanowska 2016). Leaves of shrubs growing on native sandy soils and soils recultivated with ash and sludge contained by $12 \%$ and $20 \%$ more phosphorus (Table 1 ).

Table 1. Contents of macronutrients in the leaves of sea buckthorn (Hippophae rhamnoides L.) Tabela 1. Zawartość makroskładników w liściach rosnących rokitników (Hippophae rhamnoides L.)

\begin{tabular}{lccccc}
\hline $\begin{array}{c}\text { Site } \\
\text { Lokalizacja }\end{array}$ & $\begin{array}{c}\text { Nitrogen } \\
\text { Azot N }\end{array}$ & $\begin{array}{c}\text { Phosphorus } \\
\text { Fosfor P }\end{array}$ & $\begin{array}{c}\text { Potassium } \\
\text { Potas K }\end{array}$ & $\begin{array}{c}\text { Calcium } \\
\text { Wapń Ca }\end{array}$ & $\begin{array}{c}\text { Magnesium } \\
\text { Magnez Mg }\end{array}$ \\
\hline 1 & \multicolumn{5}{c}{$\left.\cdot \mathrm{kg}^{-1} \mathrm{DM}-\mathrm{s} . \mathrm{m}.\right]$} \\
\hline 2 & $30.66^{\mathrm{a}}$ & $2.61^{\mathrm{a}}$ & $8.47^{\mathrm{c}}$ & $6.57^{\mathrm{b}}$ & $4.31^{\mathrm{b}}$ \\
\hline 3 & $32.83^{\mathrm{a}}$ & $2.79^{\mathrm{a}}$ & $11.24^{\mathrm{a}}$ & $6.23^{\mathrm{b}}$ & $7.22^{\mathrm{a}}$ \\
\hline 4 & $30.23^{\mathrm{a}}$ & $2.33^{\mathrm{b}}$ & $10.04^{\mathrm{b}}$ & $6.88^{\mathrm{b}}$ & $7.32^{\mathrm{a}}$ \\
\hline $\begin{array}{l}\text { Mean } \\
\text { Średnia }\end{array}$ & $32.76^{\mathrm{a}}$ & $2.33^{\mathrm{b}}$ & $9.77^{\mathrm{b}}$ & $8.19^{\mathrm{a}}$ & $3.44^{\mathrm{b}}$ \\
\hline $\begin{array}{l}\text { LSD }_{0.05} \text { for } \\
\text { NIR }\end{array}$ & 31.62 & 2.51 & 9.88 & 6.22 & 5.57 \\
\hline
\end{tabular}

Mean values with the same letter in each column are not significantly different at $p<0.05-$ Średnie wartości w kolumnie oznaczone tymi samymi literami nie różnią się istotnie przy $p<0,05$.

ns. - not significant difference - różnice nieistotne. 
Plants use only the most oxidized phosphorous compounds, i.e. orthophosphate; probably these elements were the most abundant in the two soil types. In other two soils, phosphorus was present at a lower level of oxidation as a result of applied fertilization and natural mineralization. Leaf samples taken a year earlier contained more nitrogen and phosphorus, an average of $39.65 \mathrm{~g} \mathrm{~N} \cdot \mathrm{kg}^{-1} \mathrm{DM}$ and $3.74 \mathrm{~g}$ of $\mathrm{P} \cdot \mathrm{kg}^{-1} \mathrm{DM}$ (Jaroszewska et al. 2016).

The amount of potassium in the sea buckthorn leaves was differentiated. Compared with the limit values given for black currant leaves, this is a low content (Łabanowska 2016). Nowakowska et al. (2017), when evaluating the influence of urban conditions on chemical composition of sea buckthorn leaves, reported analogous range. The highest proportion of this macronutrient was found in the leaves of shrubs growing on soil recultivated with ash and sludge $\left(11.24 \mathrm{~g} \mathrm{~K} \cdot \mathrm{kg}^{-1} \mathrm{DM}\right)$ - Table 1 . The amount of potassium in the sea buckthorn determined in 2015 was the same as in the 2014 samples (Jaroszewska et al. 2016).

Calcium and magnesium. The leaves of sea buckthorn bush growing on native soil and soil recultivated with ash and sludge were characterized by similar calcium content of $6.5 \mathrm{~g} \mathrm{Ca} \cdot \mathrm{kg}^{-1} \mathrm{DM}$. More calcium in the sea buckthorn leaves growing on the Odra river banks was the result of close proximity to the road.

Fertilization of the soil with coal ashes and sewage sludge resulted in the increase of magnesium content in the leaves of sea buckthorn (Hippophae rhamnoides L.) growing at these sites to the level of $7 \mathrm{~g} \mathrm{Mg} \cdot \mathrm{kg}^{-1} \mathrm{DM}$. For comparison, magnesium content in black currant leaves over $4.5 \mathrm{~g} \mathrm{Mg} \cdot \mathrm{kg}^{-1} \mathrm{DM}$ according to the National Plant Protection and Seed Inspection is considered as high (Łabanowska 2016) - Table 1. Comparing the average contents of calcium and magnesium in both years, there was an increase in the abundance of these elements in the sea buckthorn leaves in 2015 (Jaroszewska et al. 2016).

\section{Microelements (Na, Fe, Mn, Zn, Mo, Cr, Pb, Cd)}

Micronutrients stimulate the biochemical processes that occur at plants. These are elements that are essential nutrients, needed for plant growth and development, and are most effective in small quantities.

Sodium. Sodium, compared to potassium, calcium and magnesium, is not considered as a nutrient essential for plants. The amount of sodium varies within very wide limits, depending on the nature of plant. Sea buckthorn leaves growing on the banks of the Odra river, close to the road, contained a lot of sodium, which was most probably the result of using sodium chloride to clear the road in winter. The content of sodium was ten times higher than that of other plants (Table 2). Zadernowski et al. (2005) indicate that sodium is found in large quantities in the sea buckthorn berries. Intensive uptake of sodium by plants is justified by the fact that under natural conditions sea buckthorn grows over the Baltic Sea, where it forms dense scrubs on the cliff coasts and coastal dunes. The uptake of large amounts of sodium, as well as calcium and magnesium, by sea buckthorn indicates the possibility of its growing on saline and degraded soils. The usefulness of this plant species for these purposes is confirmed by other studies on this subject (Nowak and Zieliński 2009; Nowakowska et al. 2017). 
Table 2. Content of micronutrients in the leaves of sea buckthorn (Hippophae rhamnoides L.) Tabela 2. Zawartość mikroelementów w liściach rosnących rokitników (Hippophae rhamnoides L.)

\begin{tabular}{|c|c|c|c|c|c|}
\hline $\begin{array}{c}\text { Site } \\
\text { Lokalizacja }\end{array}$ & $\begin{array}{l}\text { Sodium } \\
\text { Sód } \\
\mathrm{Na}\end{array}$ & $\begin{array}{l}\text { Iron } \\
\text { Żelazo } \\
\mathrm{Fe} \\
\end{array}$ & $\begin{array}{c}\text { Manganese } \\
\text { Mangan } \\
\text { Mn }\end{array}$ & $\begin{array}{c}\text { Ratio } \\
\text { Stosunek } \\
\text { Fe: Mn } \\
\end{array}$ & $\begin{array}{c}\text { Zinc } \\
\text { Cynk } \\
\text { Zn }\end{array}$ \\
\hline \multicolumn{6}{|c|}{$\left[\mathrm{mg} \cdot \mathrm{kg}^{-1} \mathrm{DM}-\mathrm{s} . \mathrm{m}.\right]$} \\
\hline 1 & $425.3^{b}$ & $96.7^{\mathrm{c}}$ & $19.14^{\mathrm{b}}$ & 5.1 & $14.72^{\mathrm{c}}$ \\
\hline 2 & $388.3^{c}$ & $110.9^{\mathrm{b}}$ & $19.68^{b}$ & 8.7 & $19.35^{b}$ \\
\hline 3 & $351.6^{c}$ & $105.4^{\mathrm{b}}$ & $18.84^{\mathrm{b}}$ & 3.7 & $13.79^{\mathrm{c}}$ \\
\hline 4 & $3967.9^{a}$ & $259.8^{a}$ & $60.78^{a}$ & 4.3 & $26.90^{a}$ \\
\hline $\begin{array}{l}\text { Mean } \\
\text { Średnia }\end{array}$ & 1233.3 & 143.2 & 29.61 & - & 18.69 \\
\hline $\begin{array}{l}\text { LSD }_{0.05} \text { for } \\
\text { NIR }_{0,05} \text { dla }\end{array}$ & 48.22 & 8.31 & 3.667 & - & 1.568 \\
\hline
\end{tabular}

Mean values with the same letter in each column are not significantly different at $p<0.05-$ Średnie wartości w kolumnie oznaczone tymi samymi literami nie różnią się istotnie przy $p<0,05$.

Fertilization of soil with hard coal ash and sewage sludge resulted in the reduction of sodium content in leaves of sea buckthorn (Hippophae rhamnoides L.) growing at these sites to levels of 352 and $388 \mathrm{mg} \mathrm{Na} \cdot \mathrm{kg}^{-1} \mathrm{DM}$, which was probably due to the increased potassium uptake by plants (Tables 1,2 ).

Iron and manganese. Iron, as the most common trace element, participates in vital life processes such as respiration, photosynthesis, nitrate breakdown, and free nitrogen binding. Leaves of sea buckthorn growing on the banks of the Odra river contained more than twice as much iron as those of the shrubs growing on the native sandy soil, which was due to their proximity to the road. Fertilization of soil with hard coal ash and sewage sludge resulted in an increase in the amount of iron in leaves of the sea buckthorn (Hippophae rhamnoides L.) growing at these sites, by $15 \%$ and $9 \%$, respectively (Table 2 ).

Manganese is essential for plants, however their needs relative to this element are very small. Most manganese can be found in leaves, less in roots, and the least in shoots. The content of manganese in leaves was from 18.84 to $60.78 \mathrm{mg} \mathrm{Mn} \cdot \mathrm{kg}^{-1} \mathrm{DM}$ (Table 2). For comparison, according to Gawrońska-Krzywy and Gutkowska (2007), manganese content in grass is $45-160 \mathrm{mg} \mathrm{Mn} \cdot \mathrm{kg}^{-1}$. Leaves of sea buckthorn growing on the banks of the Odra river contained three times more manganese than plants growing elsewhere.

Shrub leaves contained an average of $143.2 \mathrm{mg} \mathrm{Fe} \cdot \mathrm{kg}^{-1} \mathrm{DM}$, while in previous year, they contained more iron, but there was no difference in the amount of manganese in leaves according to the years they were collected (Jaroszewska et al. 2016).

Manganese and iron, due to their properties, may act as biochemical antagonists and may compete with each other for the absorption of binding enzymes in the soil (Gudmundsdóttir et al. 2006). Only the weight ratio should be used to compare the interaction between the elements in question, and it is a simple quotient of their quantities in plants (Table 2). The Fe:Mn ratio in leaves of sea buckthorn (Hippophae rhamnoides L.) was within the range of $3.7: 1-8.7: 1$, indicating an even greater dominance of iron as compared to manganese than in the previous year $(2.9: 1-7.6: 1)$.

Zinc. The range of zinc content in plants, which regulates the carbohydrate metabolism

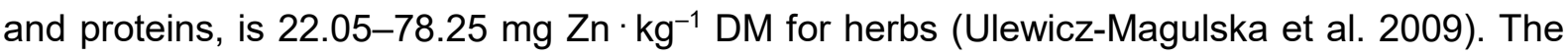
abundance of leaves of tested sea buckthorn (Hippophae rhamnoides L.) ranged from 13.79 


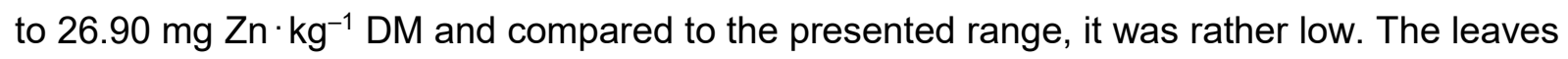
of plants growing on the banks of the Odra river contained twice as much zinc as the others (Table 2).

Zinc quantity in the sea buckthorn determined in 2015 was higher in comparison with the abundance at plants in 2014 (Jaroszewska et al. 2016).

Molybdenum, chromium, lead, and cadmium. There were no presence of molybdenum, chromium, lead, and cadmium in leaves of sea buckthorn (Hippophae rhamnoides L.).

\section{CONCLUSIONS}

1. The different sites of the growing shrubs of sea buckthorn (Hippophae rhamnoides L.) and the applied fertilization resulted in the differentiation of phosphorus, potassium, calcium, and magnesium in leaves of the plant, but no change in nitrogen content was observed.

2. Leaf samples collected a year earlier contained more nitrogen and phosphorus and less calcium and magnesium. The amount of potassium in sea buckthorn leaves in 2015 was almost the same as in the previous year.

3. Leaves of sea buckthorn growing on the banks of the Odra river contained over ten times more sodium, twice as much iron, three times as much manganese as leaves of shrubs growing elsewhere.

4. There was no difference in the amount of manganese in the leaves over the years, while those collected a year earlier contained more iron.

5. No presence of molybdenum, lead, chromium and cadmium was recorded in the leaves of sea buckthorn (Hippophae rhamnoides L.).

6. Uptake of large amounts of sodium, calcium, and magnesium by sea buckthorn indicates the possibility of its growing on saline and degraded soils.

\section{REFERENCES}

Beveridge T., Li T.S., Oomah B.D., Smith A. 1999. Sea buckthorn products: manufacture and composition. J. Agric. Food Chem. 47(9), 3480-3488. DOI: 10.1021/jf981331m.

Dulf F.V. 2012. Fatty acids in berry lipids of six sea buckthorn (Hippophae rhamnoides L., subspecies carpatica) cultivars grown in Romania. Chem. Cent. J. 6, 106. DOI: 10.1186/1752-153X-6-106.

Gawrońska Krzywy E., Gutkowska I. 2007. Zawartość makro- i mikroskładników w życicy trwałej po zastosowaniu kompostów z wycierki ziemniaczanej i komunalnego osadu ściekowego [The content of macro- and microelements in perennial ryegrass after the application of composts made of potato pulp and municipal sludge]. Woda Środ. Obsz. Wiejskie 2, 231-244. [in Polish]

Giuffrida D, Pintea A., Dugo P., Torre G., Pop R.M., Mondello L. 2012. Determination of carotenoids and their esters in fruits of sea buckthorn (Hippophae rhamnoides L.) by HPLC-DAD-APCI-MS. Phytochem. Analysis. 23, 267-273. DOI: 10.1002/pca.1353.

Gudmundsdóttir K.B., Sigurdarson S., Kristinsson J., Eiríksson T., Jóhannesson T. 2006. Iron and iron/manganese ratio in forage from Icelandic sheep farms: relation to scrapie. Acta Vet. Scand. 48, 16-21. DOI: 10.1186/1751-0147-48-16.

Heinäaho M., Pusenius J., Julkunen-Tiitto R. 2006. Effects of different organic farming methods on the concentration of phenolic compounds in sea buckthorn leaves. J. Agric. Food Chem. 54, 7678-7685. DOI: 10.1021/jf061018h. 
Jaroszewska A., Biel W., Jurgiel-Małecka G., Grajkowski J., Gibczyńska M. 2016. The influence of soil differentiation on chemical composition of sea buckthorn (Hippophaë rhamnoides L.) leaves as feed material. Folia Pomer. Univ. Technol. Stetin., Agric. Aliment., Pisc., Zootech. 39, 97-108.

Kallio H., Yang B., Peippo P. 2002. Effects of different origins and harvesting time on vitamin C, tocopherols and tocotrienols in Seabuckthorn (Hippophae rhamnoides L.) berries. J. Agric. Food Chem. 50, 6136-6142. DOI: 10.1021/jf020421v.

Kumar M.S., Dutta R., Prasad D., Misra K. 2011. Subcritical water extraction of antioxidant compounds from Seabuckthorn (Hippophae rhamnoides) leaves for the comparative evaluation of antioxidant activity. Food Chem. 127, 1309-1516. DOI: 10.1016/j.foodchem.2011.01.088.

Łabanowska B. 2016. Metodyka integrowanej produkcji porzeczki czarnej i czerwonej. Warszawa, PIORiN, 13-21. [in Polish]

Magnuszewska J., Krogulec T. 2013. Application of hot platinum microelectrodes for determination of flavonoids in flow injection analysis and capillary electrophoresis. Anal. Chim. Acta 5, 39-46. DOI: 10.1016/j.aca.2013.05.031.

Niesteruk A., Lewandowska H., Golub Ż., Świsłocka R., Lewandowski W. 2013. Zainteresujmy się rokitnikiem. Preparaty z rokitnika zwyczajnego (Hippophae rhamnoides L.) jako dodatki do żywności oraz ocena ich rynku w Polsce [Let's get interested with sea buckthorn preparations of sea buckthorn as food additives and assessment of their market in Poland]. Kosmos 62, 571-581. [in Polish]

Nowak G., Zieliński J. 2009. Wpływ warunków miejskich na wzrost i kondycję platana klonolistnego Platanus x hispanica "Acerifolia" [The influence of urban conditions on London plane tree Platanus $x$ hispanica "Acerifolia" growth and strength of the development]. Zesz. Probl. Post. Nauk Rol. 539, 537-543. [in Polish]

Nowakowska M., Ochmian I., Mijowska K. 2017. Assessment of the sea buckthorn growing in urban conditions - the quality of berries and leaves. J. Elem. 22, 399-409. DOI: 10.5601/jelem.2016.21.2.1168.

Pop R.M., Weesepoel Y., Socaciu C., Pintea A., Vincken J.P., Gruppen H. 2014. Carotenoid composition of berries and leaves from six Romanian sea buckthorn (Hippophae rhamnoides L.) varieties. Food Chem. 147, 1-9. DOI: 10.1016/j.foodchem.2013.09.083.

PN-ISO 6491:2000P. Oznaczanie zawartości fosforu. Metoda spektrometryczna. [in Polish]

PN-EN ISO 6869:2002P. Oznaczanie zawartości wapnia, miedzi, żelaza, magnezu, manganu, potasu, sodu i cynku. Metoda absorpcyjnej spektrometrii atomowej. [in Polish]

PN-EN ISO 20483:2014-02. Ziarno zbóż i nasiona roślin strączkowych. Oznaczanie zawartości azotu i przeliczanie na zawartość białka. Metoda Kjeldahla. [in Polish]

Saggu S., Divekar H.M., Gupta V., Sawhney R.C., Banerjee P.K., Kumar R. 2007. Adaptogenic and safety evaluation of seabuckthorn (Hippophae rhamnoides): A dose dependent study. Food Chem. Toxicol. 45, 609-617. DOI: 10.1016/j.fct.2006.10.008.

Saini M., Tiwari S., Prasad J., Singh S., Kumar M.S., Bala M. 2010. hippophae leaf extract concentration regulates antioxidant and prooxidant effects on DNA. J. Diet. Suppl. 7, 60-70. DOI: $10.3109 / 19390210903535027$.

Sajfrtova M. Sovova H. 2012. Solute-matrix and solute-solute interactions during supercritical fluid extraction of sea buckthorn leaves. Proc. Eng. 42, 1682-1691. DOI: 10.1016/j.proeng.2012.07.561.

Tulsawani R., Gupta R., Misra K. 2013. Efficacy of aqueous extract of Hippophae rhamnoides and its bio-active flavonoids against hypoxia-induced cell death. Indian J. Pharmacol. 45, 258-263. DOI: 10.4103/0253-7613.111943.

Ulewicz-Magulska B., Baranowska M., Wesołowski M. 2009. Assessment of the content of copper, manganese, zinc and iron in herbs and leaves of medicinal plants. Bromat. Chem. Toksykol. 42, 815-821.

Yang B., Kallio H. 2002. Composition and physiological effects of sea buckthorn (Hippophae rhamnoides L.) lipids. Trends Food Sci. Tech. 13, 160-167. DOI:10.1016/S0924-2244(02)00136-X.

Zadernowski R., Szałkiewicz M., Czaplicki S. 2005. Skład chemiczny i wartość odżywcza owoców rokitnika (Hippophaë rhamnoides L.) [Chemical composition and nutritional value of sea buckthorn fruits (Hippophae rhamnoides L.)]. PFiOW, 8-9, 56-58. [in Polish] 
Zheng X., Long W., Liu G., Zhang X., Yang X. 2012. Effect of seabuckthorn (Hippophae rhamnoides ssp. sinensis) leaf extract on the swimming endurance and exhaustive exercise-induced oxidative stress of rats. J. Sci. Food Agri. 92, 736-42. DOI: 10.1002/jsfa.4634.

Abstract. Sea buckthorn is used in the world primarily for its high nutritional value and unique healing properties. It is a plant with a small climate and soil requirements. The study was conducted to determine changes mineral compounds in leaves of sea buckthorn (Hippophae rhamnoides L. ssp. rhamnoides), depending on the substrate type and the passage of time and assessment of the potential for sea buckthorn growth on saline and degraded soil. The determined the amounts of nitrogen, phosphorus, potassium, calcium, magnesium, iron, manganese, zinc, sodium, molybdenum, chromium, lead, and cadmium. Shrubs of sea buckthorn (Hippophae rhamnoides L. ssp. rhamnoides), of which leaves were collected in June 2015, were located in four sites in Szczecin. The soils, on which sea buckthorn bushes grow are alkaline. The different sites of the growing shrubs of sea buckthorn (Hippophae rhamnoides L.) and the applied fertilization resulted in the differentiation of $\mathrm{P}, \mathrm{K}, \mathrm{Ca}$, and $\mathrm{Mg}$ in leaves of the plant, but no change in $\mathrm{N}$ content was observed. Leaf samples collected a year earlier contained more $\mathrm{N}$ and $\mathrm{P}$ and less $\mathrm{Ca}$ and $\mathrm{Mg}$. Leaves of sea buckthorn growing on the banks of the Odra river contained over ten times more $\mathrm{Na}$, twice as much $\mathrm{Fe}$, three times as much $\mathrm{Mn}$ as leaves of shrubs growing elsewhere. There was no difference in the amount of $\mathrm{Mn}$ in the leaves over the years, while those collected a year earlier contained more Fe. No presence of $\mathrm{Mo}, \mathrm{Pb}$, $\mathrm{Cr}$ and $\mathrm{Cd}$ was recorded in the leaves of sea buckthorn (Hippophae rhamnoides L.). Uptake of large amounts of $\mathrm{Na}, \mathrm{Ca}$, and $\mathrm{Mg}$ by sea buckthorn indicates the possibility of its growing on saline and degraded soils and the passage of time. 